\title{
Variation in number of trunk vertebrae and in count of costal grooves in salamanders of the family Hynobiidae
}

\author{
S.N. Litvinchuk ${ }^{1} \&$ L.J. Borkin ${ }^{2}$ \\ ${ }^{1}$ Institute of Cytology, Russian Academy of Sciences, Tikhoretsky pr. 4, 194064 St. Petersburg, Russia, e- \\ mail: slitvinchuk@yahoo.com; ${ }^{2}$ Zoological Institute, Russian Academy of Sciences, Universitetskaya nab. 1, \\ 199034 St. Petersburg, Russia, e-mail: borkin@spas.spb.su
}

Keywords: Hynobiidae, trunk vertebrae, costal grooves

\begin{abstract}
Ten species from five genera of the family Hynobiidae were studied. The number of trunk vertebrae varied between 14 and 21 , and the count of costal grooves ranged from 10 to 15 . Both the within-species variation and the within-population variation were recorded in some species. In both kinds the values of the coefficient of variation were quite low. In Salamandrella keyserlingii, the south-eastern samples markedly differed from remaining ones. Among the hynobiids, the genus Onychodactylus (both species) and Batrachuperus mustersi have higher number of vertebrae in the anterior part of trunk ( 5 and 4 , respectively, versus 3), and, thus, demonstrated a distinct position. The relation between the number of trunk vertebrae and the count of costal grooves was studied. The variation in number of trunk vertebrae across urodelan families was discussed.
\end{abstract}

\section{Content}

Introduction

Materials and methods

Results

Number of trunk vertebrae

Patterns of trunk vertebrae composition 199

Count of costal grooves 200

Discussion

201

Number of trunk vertebrae $\quad 201$

Within-population variation 201

Sexual dimorphisms 202

Geographic variation " 202

Comparison between the hynobiids and other families 204

Patterns of trunk vertebrae composition 204

Count of costal grooves

Correlating number of trunk vertebrae with count of costal grooves

Taxonomic value

Concluding remarks

Acknowledgements

References

Appendix

\section{Introduction}

Among modern tailed amphibians, the family Hynobiidae (about 40 species), distributed predominantly in temperate Asia, is an early diverged branch, which retains many primitive characters (e.g., Duellman \& Trueb, 1986; Larson \& Dimmick, 1993). Based on recent studies (Fei \& Ye, 2000a; Fu et al., 2001), approximately ten genera of the hynobiids could be recognized. The genus Hynobius is the richest one and consists of about 22 species, which may be arranged in three subgenera (Matsui et al., 1992; Borkin, 1999), namely Hynobius (about 14 species), Pseudosalamandra (7 species) and Satobius (1 species). The family also includes the genera Liua (1 species), Onychodactylus (2 species), Pachyhynobius (1 species), Protohynobius (1 species), Pseudohynobius (1 species), Ranodon (2 species), Salamandrella (1 species, which penetrates to eastern Europe), and Batrachuperus sensu lato (about 9 species). The taxonomic positions of Ranodon, Liua, Pseudohynobius, and Batrachuperus were discussed in recent papers (Fei \& Ye, 2000b; Fu et al., 2001; Kuzmin \& Thiesmeier, 2001).

Based on mitochondrial DNA study (Fu et al., 2001), it was found that the genus Batrachuperus could be split into two distinct geographic groups, probably, of generic level. The eastern (Chinese) group belongs to Batrachuperus sensu stricto and consists of six species (Fei \& Ye, 2000b; Song et al., 2001). The western (Middle East) group consists of two or three species. They may be allocated to Paradactylodon.

Hynobiids were and are a favorite model for the 
study on evolutionary morphology and lower tetrapod phylogeny (e.g., Schmalhausen, 1964; Vorobyeva, 1994). Special attention was paid to the study of the morphogenesis of vertebral column (Schmalhausen, 1957, 1958a, 1958b, 1964; Borchwardt, 1974). However, as yet, the data about the number of trunk vertebrae in hynobiids are quite scarce. In his comprehensive description of osteology of the Japanese clawed salamander, Onychodactylus japonicus, Okajima (1908) mentioned the position of the sacral vertebra in vertebral column. Later, Hilton (1948) \& Teege (1957) provided the information about vertebral morphology for four and three species of the hynobiid salamanders, respectively, including $O$. japonicus. However, even data based on the same (latter) species were conflicting. Antipenkova (1994) published a short review. on number and morphology of vertebrae in the Siberian salamander, Salamandrella keyserlingii. Some other data were also published by Deynegi (1917), Antipenkova (1982), Zhang (1985), Nambu (1991), \& Fei \& Ye (2000a).

Nevertheless, since the late $1950 \mathrm{~s}$, number of trunk vertebrae has been using in systematics of urodelans. Some papers were devoted to study geographic variation in various salamanders, mostly plethodontids, proteids and salamandrids (Brodie, 1961; Highton, 1962; Worthington \& Wake, 1972; Sket \& Arntzen, 1994; Arntzen \& Wallis, 1999; Litvinchuk \& Borkin, 2000).

As is known, urodelans, at least, at the larval stage, have external body segmentation expressed by so-called costal grooves. Since the classic monograph about the family Hynobiidae (Dunn, 1923), count of such grooves became an important taxbnomic character used for identification of species (e.g., Chang, 1936; Thorn, 1969; Thorn \& Raffaëlli, 2001). The question arises whether a correlation between the number of trunk vertebrae and count of costal grooves exists. Some authors have analysed the problem based on plethodontids and ambystomatids (e.g., Highton, 1957; Jockusch, 1997). However, hynobiids are still markedly less studied.

The goal of the present paper is to evaluate the variation in amount of both trunk vertebrae and costal grooves among representatives of the family Hynobiidae.

\section{Materials and methods}

A total of 635 adult and subadult specimens belonging to ten hynobiid species were studied. The materials studied are kept at the collections of the Department of Herpetology, Zoological Institute, Russian Academy of Sciences, St. Petersburg $(n=265)$, Department of Vertebrate Zoology, St. Petersburg State University, St. Petersburg $(n=171)$, and Zoological Museum, Moscow State University, Moscow ( $\mathrm{n}=199)$.

The number of trunk vertebrae (or "dorsal vertebrae" according to Mivart, 1870) was accounted by the number of spinal processes by means of dissection of dorsal muscles. The position of the sacrum was identified by feeling of sacral ribs on the left side of the body.

Unfortunately, various authors used different techniques of costal grooves counting. Moreover, under the same name they understood different cases. So, Dunn (1923) has applied the name "costal grooves" to all lateral body grooves situated between the fore- and hindlimb, probably, including the grooves, which touched the posterior margin of the base of hindlimbs. According to Highton (1957), the costal grooves are such grooves, which are situated between the posterior margin of the head and the anterior margin of the hindlimb. Misawa (1989) has proposed to recognize under the name "costal grooves" only lateral grooves between the fore- and hindlimbs, which did not touch limb's posterior and anterior margins, respectively. We followed Misawa. However, we counted the number of costal grooves on the left on the body side only (Misawa counted on both sides). According to Cope (1889), the grooves contacting the base of forelimbs should be named "axillary", whereas that contacting the base of hind limbs "inguinal", respectively.

\section{Results}

\section{Number of trunk vertebrae}

The number of trunk vertebrae in the family Hynobiidae varied between 14 and 21 (Table 1). The lowest number was recorded in Ranodon sibiricus, whereas the highest count was in Onychodactylus 
Table 1. Variation in number of trunk vertebrae and in count of costal grooves in ten hynobiid species.

\begin{tabular}{|c|c|c|c|c|c|c|c|c|c|}
\hline \multirow[b]{2}{*}{ Species } & \multirow{2}{*}{$n$} & \multicolumn{4}{|c|}{ Trunk vertebrae } & \multicolumn{4}{|c|}{ Costal grooves } \\
\hline & & mean & SD & $\min$ & $\max$ & mean & $\mathrm{SD}$ & $\min$ & $\max$ \\
\hline Batrachuperus mustersi & 6 & 17.3 & 0.5 & 17 & 18 & 11.8 & 0.4 & 11 & 12 \\
\hline Batrachuperus pinchonii & 2 & 15.5 & - & 15 & 16 & 10.5 & - & 10 & 11 \\
\hline Hynobius leechii & 2 & 16.0 & - & 16 & 16 & 11.5 & - & 11 & 12 \\
\hline Hynobius nigrescens & 2 & 15.0 & - & 15 & 15 & 11.0 & - & 11 & 11 \\
\hline Hynobius nebulosus & 1 & 16.0 & - & 16 & 16 & 12.0 & - & 12 & 12 \\
\hline Hynobius naevis & 3 & 16.7 & 0.6 & 16 & 17 & 12.0 & 0 & 12 & 12 \\
\hline Onychodactylus fischeri & 33 & 20.2 & 0.6 & 19 & 21 & 14.2 & 0.6 & 13 & 15 \\
\hline Onychodactylus japonicus & 5 & 17.8 & 0.4 & 17 & 18 & 11.8 & 0.4 & 11 & 12 \\
\hline Ranodon sibiricus & 77 & 15.1 & 0.3 & 14 & 16 & 10.9 & 0.4 & 10 & 12 \\
\hline Salamandrella keyserlingii & 504 & 16.9 & 0.5 & 15 & 19 & 12.0 & 0.5 & 10 & 14 \\
\hline
\end{tabular}

" $\mathrm{n}$ " is number of specimens examined; "SD" is the standard deviation.

Table 2. Distribution of number of trunk vertebrae and count of costal grooves in nine hynobiid species.

\begin{tabular}{|c|c|c|c|c|c|c|c|c|c|c|c|c|c|c|c|}
\hline \multirow[b]{2}{*}{ Species } & \multirow[b]{2}{*}{$\mathrm{n}$} & \multicolumn{8}{|c|}{ Trunk vertebrae (\%) } & \multicolumn{6}{|c|}{ Costal grooves (\%) } \\
\hline & & 14 & 15 & 16 & 17 & 18 & 19 & 20 & 21 & 10 & 11 & 12 & 13 & 14 & 15 \\
\hline Batrachuperus mustersi & 6 & & & & 67 & 33 & & & & - & 17 & 83 & & & \\
\hline Batrachuperus pinchonii & 2 & & 50 & $\mathbf{5 0}$ & & & & & & $\mathbf{5 0}$ & 50 & & & & \\
\hline Hynobius leechii & 2 & & & 100 & & & & & & & 50 & 50 & & & \\
\hline Hynobius nigrescens & 2 & & 100 & & & & & & & & 100 & & & & \\
\hline Hynobius nebulosus & 1 & & & 100 & & & & & & & & 100 & & & \\
\hline Hynobius naevis & 3 & & & 33 & 67 & & & & & & & 100 & & & \\
\hline Onychodactylus fischeri & 33 & & & & & & 9 & 67 & 24 & & & & 9 & 67 & 24 \\
\hline Onychodactylus japonicus & 5 & & & & 20 & 80 & & & & & 20 & 80 & & & \\
\hline Ranodon sibiricus & 77 & 1 & 89 & 10 & & & & & & 13 & 84 & 3 & & & \\
\hline Salamandrella keyserlingii & 504 & & 2 & 13 & 78 & 6 & 0.2 & & & 1 & 11 & 75 & 13 & 0.2 & \\
\hline
\end{tabular}

The modal classes are in bold.

fischeri. The modal number of trunk vertebrae was 15 in Ranodon sibiricus (and, probably, Hynobius nigrescens), 16 in Hynobius leechii (and, probably, Hynobius nebulosus), 17 in Salamandrella keyserlingii, Hynobius naevis and Batrachuperus mustersi, and 18 in Onychodactylus japonicus. Onychodactylus fischeri was characterized by the higher modal number, which was equal to 20 .

In the majority of species, the differences between minimum and maximurm numbers of trunk vertebrae were equal to two or less (Table 2). However, in Salamandrella keyserlingii, such differences reached four vertebrae. In three most studied species (Salamandrella keyserlingii, Ranodon sibiricus, and Onychodactylus fischeri) the coefficient of variation (CV\%) ranged between 2.2 percent and 3.0 percent. Within these species, at the level of individual populations, the variability was quite small as well. The majority of species displayed symmetrical distribution of numbers of trunk vertebrae, i.e. less and more than the modal class (Table 2).

Geographic variation was studied in two species, namely Salamandrella keyserlingii and Ranodon sibiricus. Within the former species, the salamanders from the majority of samples had, as a rule, 17 trunk vertebrae, with the averages between 16.9 and 17.4 (Table 3). However, populations distributed in the south-eastern part of the species' range had less than 16.5 trunk vertebrae (16.2-16.4 in average). Such samples were recorded in the Primorsky Territory, in the southernmost part of Khabarovsk Territory (the Ussuri River Valley), as well as, in the southeast of Manchuria (north-eastern China). Unlike Salamandrella keyserlingii with the vast distribution from eastern Europe to Kamchatka Peninsula (Fig. 1), Ranodon sibiricus is characterized 
Table 3. Geographic variation in number of trunk vertebrae (TV) and in count of costal grooves (CG) in eleven samples of Salamandrella keyserlingii and two samples of Ranodon sibiricus.

\begin{tabular}{|c|c|c|c|c|c|c|c|c|c|c|c|c|c|c|}
\hline \multirow[b]{2}{*}{ Samples } & \multirow[b]{2}{*}{$\mathrm{n}$} & \multicolumn{2}{|c|}{ Mean \pm SD } & \multicolumn{6}{|c|}{ TV (\%) } & \multicolumn{5}{|c|}{ CG $(\%)$} \\
\hline & & TV & $\mathrm{CG}$ & 14 & 15 & 16 & 17 & 18 & 19 & 10 & 11 & 12 & 13 & 14 \\
\hline & & Salamandr & a keyserlingit & & & & & & & & & & & \\
\hline 1 Udmurt Republic & 7 & $16.9 \pm 0.4$ & $12.1 \pm 0.7$ & & & 14 & 86 & & & & 14 & $\mathbf{5 7}$ & 29 & \\
\hline 2 Sverdlovsk Province & 175 & $17.0 \pm 0.3$ & $12.1 \pm 0.4$ & & & 3 & 92 & 5 & & & 2 & 86 & 11 & \\
\hline 3 Tomsk Province & 5 & $17.4 \pm 0.5$ & $12.4 \pm 0.5$ & & & & 75 & 25 & & & & 63 & 37 & \\
\hline 4 Buryatia Republic & 19 & $16.9 \pm 0.2$ & $12.1 \pm 0.3$ & & & 5 & 95 & & & & & 89 & 11 & \\
\hline 5 Mongolia & 13 & $17.0 \pm 0$ & $12.2 \pm 0.4$ & & & & 100 & & & & & 85 & 15 & \\
\hline 6 Amur Province & 24 & $17.1 \pm 0.6$ & $12.2 \pm 0.6$ & & & 17 & 63 & 17 & 4 & & 13 & 63 & 21 & 4 \\
\hline 7 Yakutia Republic & 73 & $17.0 \pm 0.2$ & $12.1 \pm 0.3$ & & & 1 & 95 & 4 & & & 1 & 92 & 7 & \\
\hline 8 Magadan Province & 16 & $17.3 \pm 0.5$ & $12.4 \pm 0.5$ & & & & 69 & 31 & & & & 63 & 37 & \\
\hline 9 Kamchatka Province & 76 & $17.1 \pm 0.3$ & $12.3 \pm 0.5$ & & & 1 & 87 & 12 & & & & 71 & 29 & \\
\hline 10 Khabarovsk Territory & 8 & $16.4 \pm 0.7$ & $11.5 \pm 0.5$ & & 11 & 38 & 51 & & & & & $\mathbf{5 0}$ & 50 & \\
\hline 11 Primorsky Territory & 83 & $16.2 \pm 0.6$ & $11.4 \pm 0.6$ & & 13 & 57 & 30 & & & & 6 & 49 & 42 & 2 \\
\hline \multirow[t]{2}{*}{12 China (north-east) } & 3 & $16.3 \pm 0.6$ & $11.7 \pm 0.6$ & & & 67 & 33 & & & & & 33 & 67 & \\
\hline & & \multicolumn{2}{|c|}{ Ranodon sibiricus } & & & & & & & & & & & \\
\hline Tekeli and Kopal towns & 60 & $15.1 \pm 0.4$ & $10.9 \pm 0.4$ & & 2 & 86 & 12 & & & & 10 & 87 & 3 & \\
\hline Jukentas Pass & 17 & $15.1 \pm 0.2$ & $10.8 \pm 0.4$ & & & 94 & 6 & & & & & 24 & 76 & \\
\hline
\end{tabular}

The modal classes are bold.

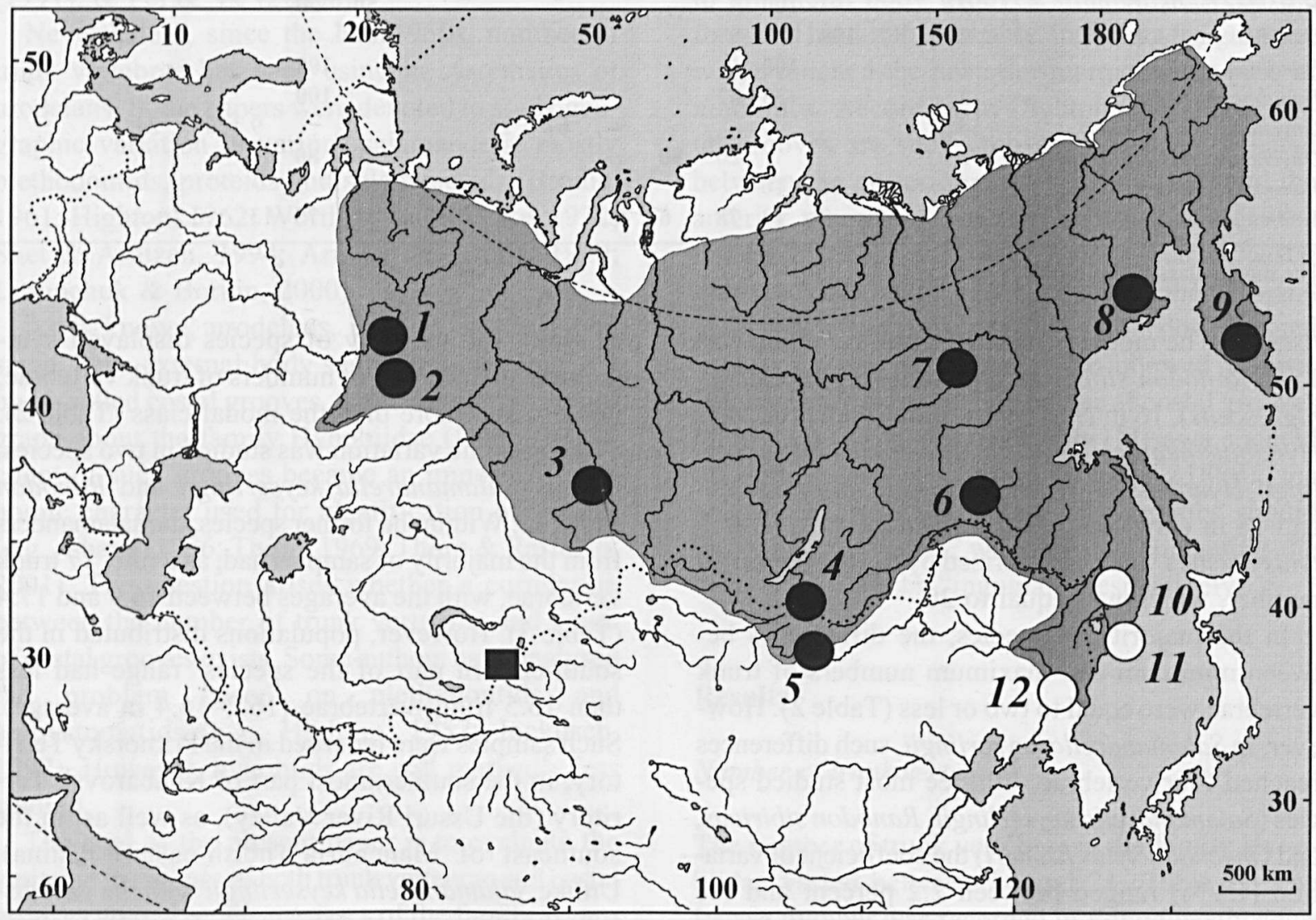

Fig. 1. The distribution of Salamandrella keyserlingii (grayish area) and Ranodon sibiricus (square) with localities studied. Black circles designate samples of $S$. keyserlingii with average number of trunk vertebrae more than 16.5, open circles - less than 16.5 . 
by a relatively small range in Central Asia, which consists of two semi-isolated parts in the Dzhungarsky Alatau Mountains (Brushko et al., 1988; Kuzmin et al., 1998; our data). The comparison of samples from these parts did not reveal any significant differences in number of trunk vertebrae (Table 3).

Sexual dimorphism was studied in the Tekeli sample of Ranodon sibiricus only (20 males and 11 females). Both sexes had almost equal number of trunk vertebrae.

\section{Patterns of trunk vertebrae composition}

The trunk portion of the vertebral column may be separated in three segments (Fig. 2). The anterior part consists of vertebrae, which are situated between the atlas and the posterior margin of the forelimb base. The middle part includes vertebrae, which are situated between the posterior margin of the forelimb base and anterior margin of the hindlimb base. The posterior part of the trunk covers the vertebrae lying between the anterior margin of the hindlimb base and the sacral vertebra.

In these three parts, the composition of trunk in terms of number of vertebrae was variable, but with some limitations. We recognized 17 patterns (Table 4). The anterior part of the trunk was less variable, and we failed to find any case of within-species variation. Based on number of vertebrae in this part, all species examined could be arranged between three groups. The first group (with 5 vertebrae) consists of two species of the genus Onychodactylus, the second group (4 vertebrae) includes Batrachuperus mustersi only, and the third group (3 vertebrae) contains of Batrachuperus pinchonii, Hynobius leechii, $H$. nigrescens, $H$. nebulosus, $H$. naevis, Ranodon sibiricus, and Salamandrella keyserlingii.

The composition of the middle part of trunk demonstrated markedly more variation (Table 4). Number of vertebrae in this part ranged between 11 and 16 , whereas that in the posterior part had no or one vertebra only. Based on the compositions of the middle and posterior trunk parts, theoretically, twelve combinations would be possible. However, we recorded only eleven patterns. Unlike the anterior part, the variation in number of vertebrae was found both between species and within some species. In this aspect, Salamandrella keyserlingii showed the maximum variability, with eight patterns, whereas Ranodon sibiricus had five ones, and Onychodactylus fischeri three ones. Unfortunately, other species (with one or two patterns) were represented by too small samples.

Five hynobiid species (Table 4) displayed the variation in absence/presence of the vertebra in the posterior part of the trunk. The most specimens of Ranodon sibiricus $(80 \%$, the patterns $3 / 11 / 0,3 / 12 /$ 0 and $3 / 13 / 0$ ) had no vertebrae in this part of trunk, whereas Salamandrella keyserlingii, probably, together with Hynobius naevis (too small sample), had one vertebra. In both geographic entities of $S$.

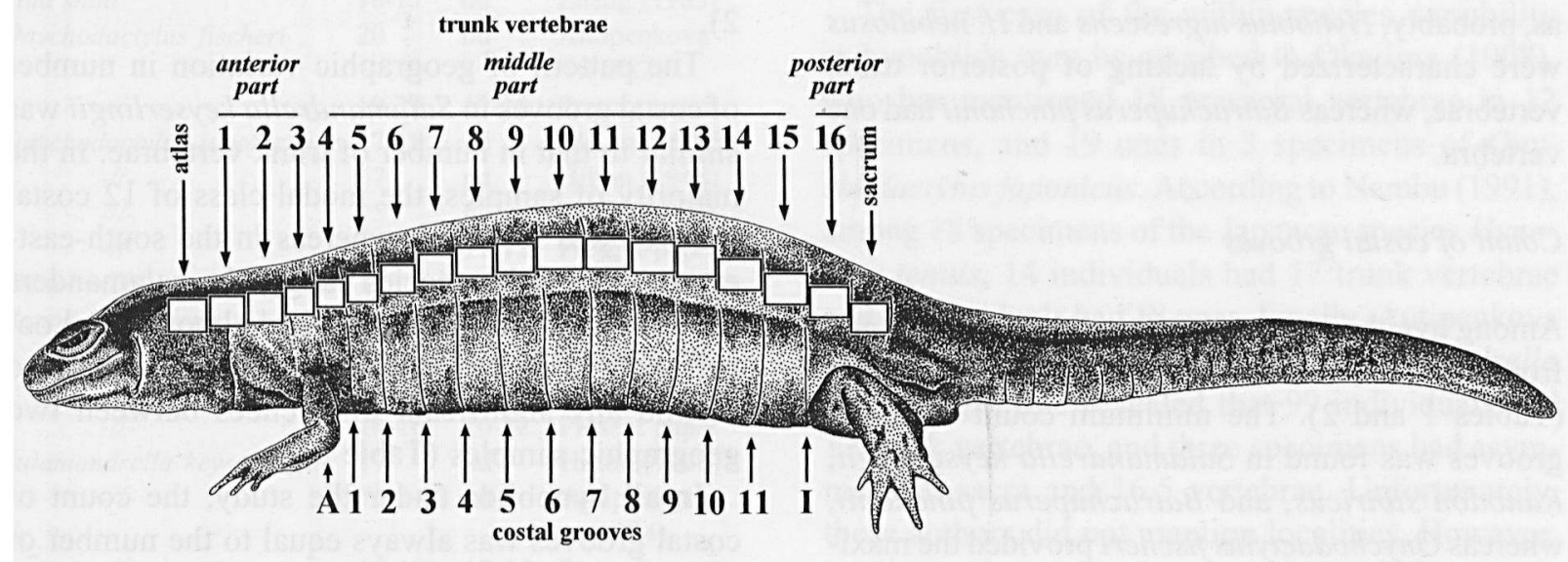

Fig. 2. The scheme of distribution of trunk vertebrae and costal grooves in Salamandrella keyserlingii. "A" is the axillary, and "I" is the inguinal grooves. 
Table 4. The frequency of trunk patterns (percent) expressed by number of vertebrae in anterior/middle/posterior parts of trunk in hynobiids.

\begin{tabular}{|c|c|c|c|c|c|c|c|c|c|c|c|c|}
\hline Pattern & $\begin{array}{l}\text { B.m. } \\
(6)\end{array}$ & $\begin{array}{l}\text { B.p. } \\
\text { (2) }\end{array}$ & $\begin{array}{l}\text { H.l. } \\
(2)\end{array}$ & $\begin{array}{l}\text { H.ni. } \\
(2)\end{array}$ & $\begin{array}{l}\text { H.ne. } \\
\text { (1) }\end{array}$ & $\begin{array}{l}\text { H.na. } \\
\text { (3) }\end{array}$ & $\begin{array}{l}\text { H.t. } \\
\text { (18) }\end{array}$ & $\begin{array}{l}\text { O.f. } \\
(33)\end{array}$ & $\begin{array}{l}\text { O.j. } \\
(5)\end{array}$ & $\begin{array}{l}\text { R.s. } \\
\text { (77) }\end{array}$ & $\begin{array}{l}\text { S.k. }^{1} \\
(410)\end{array}$ & $\begin{array}{l}\text { S.k. } \\
(94)\end{array}$ \\
\hline $3 / 11 / 0$ & & & & & & & & & & 1 & & \\
\hline $3 / 11 / 1$ & & 50 & & & & & & & & 12 & & 5 \\
\hline $3 / 12 / 0$ & & & & 100 & & & & & & 76 & & 7 \\
\hline $3 / 12 / 1$ & & 50 & 50 & & & & & & & 8 & 2 & 41 \\
\hline $3 / 13 / 0$ & & & 50 & & 100 & 33 & 72 & & & 3 & 1 & 14 \\
\hline $3 / 13 / 1$ & & & & & & 67 & 6 & & & & 81 & 30 \\
\hline $3 / 14 / 0$ & & & & & & & 22 & & & & 8 & 2 \\
\hline $3 / 14 / 1$ & & & & & & & & & & & 8 & \\
\hline $3 / 15 / 1$ & & & & & & & & & & & 0.2 & \\
\hline $4 / 12 / 1$ & 17 & & & & & & & & & & & \\
\hline $4 / 13 / 0$ & 50 & & & & & & & & & & & \\
\hline $4 / 13 / 1$ & 33 & & & & & & & & & & & \\
\hline $5 / 12 / 0$ & & & & & & & & & 20 & & & \\
\hline $5 / 13 / 0$ & & & & & & & & & 80 & & & \\
\hline $5 / 14 / 0$ & & & & & & & & 9 & & & & \\
\hline $5 / 15 / 0$ & & & & & & & & 67 & & & & \\
\hline $5 / 16 / 0$ & & & & & & & & 24 & & & & \\
\hline
\end{tabular}

B.m. is Batrachuperus mustersi (see Appendix); B.p. is B. pinchonii; H.l. is Hynobius leechii; H.ni. is H. nigrescens; H. ne. is H. nebulosus; H. na. is $H$. naevis; O.f. is Onychodactylus fischeri; O.j. is O. japonicus; R. s. is Ranodon sibiricus; S.k.' is samples $1-9$ of Salamandrella keyserlingii; S.k. ${ }^{2}$ is samples $10-12$ of the same species; and H.t. is Hynobius tenuis (Nambu, 1991). Sample sizes are given in brackets.

keyserlingii, specimens with one posterior trunk vertebrae were predominant ( $76 \%$ and $91 \%)$. Batrachuperus mustersi (and, probably, Hynobius leechii) was characterized by equal amount of specimens with absence or presence of posterior trunk vertebra. Unlike these five species, other hynobiids showed no within-species variation in the posterior part of trunk. They could be separated in two groups: both species of the genus Onychodactylus as well as, probably, Hynobius nigrescens and $H$. nebulosus were characterized by lacking of posterior trunk vertebrae, whereas Batrachuperus pinchonii had one vertebra.

\section{Count of costal grooves}

Among hynobiids, number of costal grooves ranged from 10 to 15 , with the modal class of 12 grooves (Tables 1 and 2). The minimum count of costal grooves was found in Salamandrella keyserlingii, Ranodon sibiricus, and Batrachuperus pinchonii, whereas Onychodactylus fischeri provided the maximum amount (Table 1). Parallel to trunk vertebrae, the differences between the minimum and maxi- mum numbers of costal grooves were equal to two or less in the majority of species. However, in Salamandrella keyserlingii, again, such differences reached four grooves. The within-species variation (CV\%) in number of costal grooves ranged between 4.2 percent and 4.6 percent, i.e. this was slightly higher than in number of trunk vertebrae. The distribution of count of costal grooves around the modal class was symmetrical in all species examined (Table 2).

The pattern of geographic variation in number of costal grooves in Salamandrella keyserlingii was similar to that in number of trunk vertebrae. In the majority of samples, the modal class of 12 costal grooves was recorded, whereas in the south-eastern corner of the species range, the salamanders with 11 or 12 costal grooves had almost equal occurrence (Table 3). In Ranodon sibiricus, we failed to find any significant differences between two geographic samples (Table 3 ).

In all hynobiids under the study, the count of costal grooves was always equal to the number of vertebrae in the middle part of trunk minus one (Fig. 2). 


\section{Discussion}

\section{Number of trunk vertebrae}

The literature provided quite scarce information in total about eleven species of the hynobiids (Okajima, 1908; Deynegi, 1917; Hilton, 1948; Teege, 1957; Antipenkova, 1982, 1994; Zhang, 1985; Nambu, 1991; Fei \& Ye, 2000a). Our and published data

Table 5. Number of trunk vertebrae (TV) and count of costal grooves (CG) in various hynobiids.

\begin{tabular}{|c|c|c|c|}
\hline Species & TV & CG & References \\
\hline Batrachuperus mustersi & $17-18$ & $11-12$ & Present paper \\
\hline Batrachuperus pinchonii & 17 & nd & Hilton (1948) \\
\hline$-/ /-$ & $15-16$ & $10-11$ & Present paper \\
\hline Batrachuperus persicus & nd & $11-12$ & Stöck (1999) \\
\hline Batrachuperus gorganensis & nd & $11-12$ & $-/ /-$ \\
\hline Hynobius abei & nd & 11 & Misawa (1989) \\
\hline Hynobius dunni & nd & $11-12$ & $-/ /-$ \\
\hline Hynobius kimurae & nd & 13 & $-/ /-$ \\
\hline Hynobius leechii & 16 & nd & Hilton (1948) \\
\hline$-/ /-$ & 16 & $11-12$ & Present paper \\
\hline Hynobius lichenatus & nd & $10-12$ & Misawa (1989) \\
\hline Hynobius naevis & $16-17$ & 12 & Present paper \\
\hline Hynobius nebulosus & nd & $12-13$ & Misawa (1989) \\
\hline$-/ /-$ & 16 & 12 & Present paper \\
\hline Hynobius nigrescens & nd & $10-12$ & Misawa (1989) \\
\hline$-/ /-$ & 15 & 11 & Present paper \\
\hline Hynobius sp. [peropus] & 15 & nd & Teege (1957) \\
\hline Hynobius retardatus & 15 & nd & $-/ 1-$ \\
\hline$-/ /-$ & nd & 11 & Misawa (1989) \\
\hline Hynobius steinegeri & nd & 13 & $-/ /-$ \\
\hline Hynobius tenuis & $17-18$ & $12-13$ & Nambu (1991) \\
\hline Hynobius tokyoensis & nd & $11-13$ & Misawa (1989) \\
\hline Hynobius tsuensis & nd & 13 & $-/ /-$ \\
\hline Liua shihi & $16-17$ & nd & Zhang (1985) \\
\hline Onychodactylus fischeri & 20 & nd & $\begin{array}{c}\text { Antipenkova } \\
\text { (1982) }\end{array}$ \\
\hline$-/ /-$ & $19-21$ & $13-15$ & Present paper \\
\hline Onychodactylus japonicus & $17-18$ & nd & Okajima (1908) \\
\hline$-/ /-$ & 17 & nd & Hilton (1948) \\
\hline$-/ /-$ & 15 & nd & Teege (1957) \\
\hline$-/ /-$ & $17-18$ & $11-12$ & Present paper \\
\hline Protohynobius puxiongensis & 17 & nd & Fei, Ye (2000a) \\
\hline Ranodon sibiricus & 17, & nd & Deynegi (1917) \\
\hline$-/ /-$ & 15 & nd & $\begin{array}{c}\text { Antipenkova } \\
\text { (1982) }\end{array}$ \\
\hline$-/ /-$ & $14-16$ & $10-12$ & Present paper \\
\hline Salamandrella keyserlingii & 17 & nd & Hilton (1948) \\
\hline$-/ /-$ & $16.5-17$ & nd & $\begin{array}{c}\text { Antipenkova } \\
\text { (1994) }\end{array}$ \\
\hline$-/ /-$ & $15-19$ & $10-14$ & Present paper \\
\hline
\end{tabular}

"nd" means no data. are in agreement, except three cases (Table 5). According to Deynegi (1917), Ranodon sibiricus had 17 trunk vertebrae (instead of 14-16 in our study). A similar case was with Batrachuperus pinchonii. Hilton (1948) considered that this species had 17 trunk vertebrae. However, we observed only 15-16 ones. Such differences might be explained by geographic variation or by impact of small sample size. Probably, both authors studied only a few specimens or even one specimen (they provided no data about sample size and locality). For Batrachuperus pinchonii, the problem with species identification may also be not excluded (see Fu et al., 2001). Teege (1957) mentioned 15 trunk vertebrae for Onychodactylus japonicus, whereas other authors, including ours, calculated $17-18$ vertebrae (Table 5).

Unlike other authors, we studied the within-species variation for three hynobiid species, which were represented by relatively good samples with 33 or more specimens (Table 1). This variation includes two categoriës: within-population and geographic (between-population) variations.

\section{Within-population variation}

In our opinion, this term is not a synonym of individual variation although the latter should be included. For instance, in case of a structured population, samples from different subpopulations might demonstrate some variation as well. Moreover, sexual dimorphisms could be recognized as a special case of within-population variation.

The first case of the within-species variability in hynobiids may be ascribed to Okajima (1908), who has mentioned 18 presacral vertebrae in 12 specimens, and 19 ones in 3 specimens of Onychodactylus japonicus. According to Nambu (1991), among 18 specimens of the Japanese species Hynobius tenuis, 14 individuals had 17 trunk vertebrae and 4 individuals had 18 ones. Finally, Antipenkova (1994) studied 102 specimens of Salamandrella keyserlingii. She revealed that 99 individuals had 17 trunk vertebrae, and three specimens had asymmetrical sacra and 16.5 vertebrae. Unfortunately, these authors did not mention localities. However, we know that Antipenkova worked with the sample from the Ekaterinburg [former Sverdlovsk] area, 
Middle Ural Mountains, and this is a classic locality for the long-term study of the species by Russian researchers. The within-population variability should be not a rare phenomenon because we found it for seven of ten hynobiid species (other species were represented by one or two specimens only).

Apart from hynobiids, a true within-population variation has been recorded in other families. For instance, Highton (1960) \& Jockusch (1997) described such variability ("intrapopulational variation"), with the largest differences in number of trunk vertebrae (up to four vertebrae), for some samples of the plethodontid salamanders Plethodon cinereus and Batrachoseps attenuatus, respectively. Numerous other cases associated with the family Salamandridae were published by Gerecht (1929) for European newts, Triturus ["Triton"] cristatus and T. vulgaris ["taeniatus"], as well as by Crnobrnja-Isailović et al. (1997), Arntzen \& Wallis (1999), and by us (Litvinchuk, 1998; Litvinchuk \& Borkin, 2000; Litvinchuk et al., 2001a) for the Triturus cristatus complex.

Based on published data provided by various authors, we calculated values of the coefficient of variation (CVs) for some well-studied species from six families, namely dicamptodontids, hynobiids, rhyacotritonids, plethodontids, proteids, and salamandrids (Table 6). Across species of these families, the level of within-population variation proved to be quite similar and low, and the CVs ranged between $0 \%$ and $4.3 \%$. The CVs for hynobiids were within these limits $(0-4.3 \%)$.

\section{Sexual dimorphisms}

Such a kind of variation has been found in the Californian plethodontid salamander Batrachoseps attenuatus (Jockusch, 1997) and in the European newts of the Triturus cristatus complex (CrnobrnjaIsailović et al., 1997). Unfortunately, in the hynobiids examined by us, sexual differences are not expressed in external characters, except the breeding time. Our study was based mostly on the museum collections, and we failed to identify reliably the sex of the most individuals, without dissections (in exception of one sample of Ranodon sibiricus).

\section{Geographic variation}

Among hynobiids, we found geographic variation only in a case of Salamandrella keyserlingii (Table 3 ). However, the differences between samples from the south-east and other parts of the species' distribution are not surprising. Bassarukin \& Borkin (1984) pointed out some peculiarities of populations from Primorsky Territory. For instance, local salamanders have an unusual shape of egg-sacks (Korotkov, 1977) and shorter larval development (Korotkov, 1977; Sapozhnikov, 1990; Vorobyeva et al., 1999). The Primorsky salamanders also differ by the reproduction habitat (Kuzmin, 1990) and genome size (Litvinchuk et al., 2001b) as well as by allozymes (our unpublished data). Therefore, geographic peculiarities in Salamandrella keyserlingii may be explained by distinct taxonomic position of the Primorsky samples.

Geographic variation has also been described for salamanders from other families. The differences in number of trunk vertebrae have been used for discrimination of subspecies, for instance, in Plethodon cinereus (Highton \& Grobman, 1956), in Proteus anguinus (Sket \& Arntzen, 1994), and in Triturus dobrogicus (Litvinchuk \& Borkin, 2000).

Geographic variation estimated by us for various species of urodelans was low (Table 6), with the minimum value in Triturus cristatus $(\mathrm{CV}=1.0 \%)$ and with the maximum value in Triturus vittatus ( $\mathrm{CV}=5.1 \%$ ). In five species of hynobiids, the CVs ranged between $2.2 \%$ and $3.0 \%$.

Therefore, the levels of variation in number of trunk vertebrae, expressed by $\mathrm{CVs}$, both within and between populations, were quite similar in species from various urodelan families. The low values of $\mathrm{CVs}$ reflect the relatively high stability in this character among Caudata. However, the situation may be different in various genera even for the same family. For instance, in plethodontids, the modal number of trunk vertebrae is variable (19-22) in Batrachoseps whereas, by contrast, the number is fixed (14) for numerous species of Bolitoglossa (Jockusch, 1997; Parra-Olea \& Wake, 2001).

As a rule, the differences between the lowest and the highest numbers of trunk vertebrae within a species are equal to 1-3 vertebrae. This was found in various urodelan families, with both lower and 
Table 6. Within-species variation (WSV; overall, for several samples) and range of within-population variation (WPV) in some urodelans, estimated by the coefficient of variation (percent). All CV's were calculated by us on the base of referenced data.

\begin{tabular}{|c|c|c|c|c|c|}
\hline Species & $\mathrm{N}_{\text {samples }}$ & $\mathrm{N}_{\text {specimens }}$ & WSV & WPV & References \\
\hline 11. & \multicolumn{4}{|c|}{ Dicamptodontidae } & \\
\hline Dicamptodon aterrimus & 4 & 107 & 2.9 & $0-2.3$ & Nussbaum (1976) \\
\hline D. copei & 7 & 183 & 3.2 & $0-3.0$ & $-/ /-$ \\
\hline D. ensatus & 2 & 24 & 0 & 0 & $-/ /-$ \\
\hline D. tenebrosus & 12 & 307 & 1.4 & $0-2.2$ & $-/ /-$ \\
\hline \multicolumn{6}{|c|}{ Hynobiidae } \\
\hline Hynobius tenuis & $?$ & 18 & 2.5 & - & Nambu (1991) \\
\hline Onychodactylus fischeri & 1 & 33 & - & 3.0 & Present paper \\
\hline Onychodactylus japonicus & $?$ & 18 & 2.2 & - & Okajima (1908) \\
\hline Ranodon sibiricus & 2 & 77 & 2.2 & $1.6-2.3$ & Present paper \\
\hline Salamandrella keyserlingii & 1 & 102 & - & 0.5 & Antipenkova (1994) \\
\hline$-/ /-$ & 11 & 504 & 3.0 & $0-4.3$ & Present paper \\
\hline \multicolumn{6}{|c|}{ Plethodontidae } \\
\hline Aneides flavipunctatus & 41 & 1213 & 3.3 & $0-3.2$ & Lynch (1981) \\
\hline Ensatina eschscholtzii & $?$ & 431 & 1.2 & - & Frolich (1991) \\
\hline Plethodon cinereus & 8 & 3399 & 3.3 & $2.2-2.6$ & Highton (1960) \\
\hline \multicolumn{6}{|c|}{ Proteidae } \\
\hline Necturus maculosus & 1 & 27 & - & 2.7 & Parker (1896) \\
\hline$-/ /-$ & 1 & 30 & - & 4.0 & Waite (1897) \\
\hline$-1 /-$ & $?$ & 127 & $1.4 \bullet$ & - & Smallwood (1908) \\
\hline Proteus anguinus & 4 & 78 & - & $1.7-2.4$ & Sket, Arntzen (1994) \\
\hline \multicolumn{6}{|c|}{ Rhyacotritonidae } \\
\hline Rhyacotriton cascadae & 2 & 55 & 2.8 & $1.0-3.0$ & Good, Wake (1992) \\
\hline R. variegatus & 3 & 81 & 2.9 & $0-3.1$ & $-/ /-$ \\
\hline \multicolumn{6}{|c|}{ Salamandridae } \\
\hline Nothophthalmus viridescens & 1 & 30 & - & 2.3 & Moment (1949) \\
\hline Triturus cristatus & 1 & 162 & - & 1.6 & Gerecht (1929) \\
\hline$-/ 1-$ & $?$ & 44 & 1.0 & - & Lanza et al. (1994) \\
\hline$-/ /-$ & 3 & 54 & 2.0 & $1.4-2.2$ & Crnobrnja-Isailović et al. (1997) \\
\hline$-1 /-$ & 4 & 165 & 1.8 & $0.9-3.0$ & Litvinchuk (1998) \\
\hline T. carnifex & $?$ & 148 & 2.1 & - & Lanza et al. (1994) \\
\hline$-1 /-$ & 23 & 421 & 2.1 & $0-3.2$ & Crnobrnja-Isailović et al. (1997) \\
\hline T. dobrogicus & $?$ & 14 & 3.1 & - & Lanza et al. (1994) \\
\hline$-1 /-$ & 6 & 95 & 3.6 & $2.3-4.3$ & Crnobrnja-Isailović et al. (1997) \\
\hline$-/ /-$ & 3 & 142 & 3.6 & $2.4-3.8$ & Litvinchuk, Borkin (2000) \\
\hline T. karelinii & $?$ & 40 & 2.3 & - & Lanza et al. (1994) \\
\hline$-/ 1-$ & 5 & 110 & 3.6 & $2.1-3.5$ & Crnobrnja-Isailović et al. (1997) \\
\hline$-/ /-$ & 3 & 73 & 2.5 & $2.2-2.7$ & Litvinchuk (1998) \\
\hline T. montandoni & $?$ & 33 & 3.6 & - & Arntzen, Olgun (2000) \\
\hline T. vittatus & $?$ & 78 & 5.1 & - & $-/ 1-$ \\
\hline T. vulgaris & 1 & 176 & - & 3.7 & Gerecht (1929) \\
\hline
\end{tabular}

higher vertebral count. However, in Proteus anguinus some individuals can differ by eight trunk vertebrae (Estes, 1981; Sket \& Arntzen, 1997). Among hynobiids, the majority of species also showed small within-species differences estimated by 1-2 trunk vertebrae. Nevertheless, as a whole species, Salamandrella keyserlingii demonstrated higher plasticity because such differences can reach up to four vertebrae. However, at the level of individual samples, differences between individuals did not excess three vertebrae (e.g., 16-19 trunk vertebrae in Chernyaevo sample, Amur Province).

The variation in number of trunk vertebrae can be influenced by various internal and external factors. Parallel to fishes, some authors provided evidences that the temperature of development affects 
the number of vertebrae in urodelans as well (Orska \& Imiolek, 1962; Lindsey, 1966; Peabody \& Brodie, 1975; Jockusch, 1997). Curiously, in Ambystoma maculatum, the number of vertebrae increased with increasing salinity, and there was no effect of photoperiod (Peabody \& Brodie, 1975). However, Highton (1960) \& Jockusch (1997) suggested that the geographic variation is resulted largely from genetic variation.

\section{Comparison between the hynobiids and other families}

We summarized published and our data on number of trunk vertebrae in various families (Table 7).

Table 7. The number of trunk vertebrae in various families of urodelans.

\begin{tabular}{lll}
\hline Family & Range & References \\
\hline Sirenidae & about $32-42 *$ & Lucas, 1886; Hilton, 1948 \\
Cryptobranchidae & $18-22$ & Chang, 1936; Hilton, 1948 \\
Hynobiidae & $14-21$ & Present paper \\
Proteidae & $16-36$ & Estes, 1981 \\
Plethodontidae & $13-23$ & Jockusch, 1997 \\
Amphiumidae & $60-64$ & Lucas, 1886; Teege, 1957 \\
Rhyacotritonidae & $14-17$ & Good, Wake, 1992 \\
Dicamptodontidae & $14-15$ & Nussbaum, 1976 \\
Ambystomatidae & $13-15$ & Teege, 1957 \\
Salamandridae & $11-18$ & Teege, 1957; Litvinchuk, \\
& $\cdot$ & Borkin, 2000 \\
\hline
\end{tabular}

* Hoffmann (1878) erroneously mentioned that Siren lacertina has 63 trunk vertebrae.

Among Caudata, vertebral count ranged from 11 (Salamandridae) to 64 (Amphiumidae). The majority of families have the number of trunk vertebrae, which are less than 23. The Hynobiidae also belong to this group. Considerably higher numbers of trunk vertebrae are characteristic of proteids (Proteus), sirenids, and amphiumids. Remarkably, these water inhabitants are obligatory neotenics with the eel-like body and reduced limbs. Interestingly, number of trunk vertebrae is associated with mode of life in the European newts of the Triturus cristatus group. The Danube newt, $T$. dobrogicus has more elongated body, relatively reduced limbs and more aquatic mode of life in comparison with other species (for instance, T. marmoratus or T. karelinii).
Indeed, the former newt has higher number of trunk vertebrae rather than others, namely $15-18$ versus 12-14 or 13-15 (Crnobrnja-Isailović et al., 1997; Litvinchuk, 1998; Arntzen \& Wallis, 1999; Litvinchuk \& Borkin, 2000; our unpublished data).

Although terrestrial mode of life tends to lead to more robust body with lower number of trunk vertebrae, fossoriality may be associated with elongated body, and such an elongation may be achieved via an increase in number of trunk vertebrae. Jockusch (1997) discussed such possibilities for evolution in some plethodontids.

\section{Patterns of trunk vertebrae composition}

As mentioned above, in hynobiids (Table 4), the base of forelimb is fixed by its posterior margin to the third trunk vertebrae, except the genus Onychodactylus (the fifth vertebrae) and Batrachuperus mustersi (the fourth vertebrae). Interestingly, such a 3rd-vertebral position is also characteristic of ambystomatids and of the majority of plethodontids (Highton, 1957). However, in larvae of the Triturus cristatus complex, the base is fixed to the second, rarely third (1.6\%), vertebra (Litvinchuk, 1998). Based on pictures published by Cope (1889), Rabb (1965), Meyer-Rochow \& Asashima (1988), Sket \& Arntzen (1994), Parra-Olea \& Wake (2001), and Chan et al. (2001), we concluded that the fixation of the forelimbs in ambystomatids (Ambystoma maculatum), cryptobranchids (Cryptobranchus alleghiensis), dicamptodontids (Dicamptodon tenebrosus), plethodontids (Chiropterotriton magnipes, Lineatriton lineolus, Pseudoeurycea leprosa, Oedipina stenopodia and some species of the genus Batrachoseps), proteids (Necturus maculatus and Proteus anguinus), salamandrids (Paramesotriton hongkongensis, Pachytriton labiatus, Cynops pyrrhogaster and Cynops cyanurus) and sirenids ( $\mathrm{Si}$ ren lacertina) is also shifted to the second or third trunk vertebra (perhaps, in Amphiuma tridactylum it is shifted to the first vertebra). Therefore, the genus Onychodactylus and Batrachuperus mustersi have a unique position among urodelans. Thus, higher number of vertebrae in the anterior part of trunk should be recognized as an advanced (apomorphic) character.

Unlike the anterior part, number of vertebrae in 
the posterior part of trunk can be more variable within a population. However, the range of variation is not wide because of shortedness of the posterior part of trunk ( 0 to 2 vertebrae in urodelans in general). Number of vertebrae is equal to 0 or 1 in hynobiids (Table 4), 0 in ambystomatids and plethodontids (Highton, 1957), and 1, rarely 0 or 2 , in salamandrids (Litvinchuk, 1998).

\section{Count of costal grooves}

Although number of costal grooves was (and is) traditionally applied to the taxonomy of the hynobiids, nevertheless, approaches of various authors to count these grooves were quite different. Misawa (1989) has elaborated a unified method to count of grooves, which did not contact with the bases of limbs. He has also pointed out possible differences in the number of costal grooves on the left and right sides of the same individuals. Later, similar method has been accepted by Nambu (1991), Stöck (1999) and by us (this paper). Currently, reliable counts taken by this method are provided for twenty hynobiid species (Table 5).

Among hynobiids, number of costal grooves varied between 10 and 15 . The modal number for the family is 12 . As a whole, the family seems to be quite homogeneous, except Onychodactylus fischeri, which has 13-15 costal grooves (Table 5).

Significant geographic variation was revealed in Salamandrella keyserlingii. So, according to Ostashko (1981) \& Borkin (1994), the samples from Yakutia, Buryatia, \& Sverdlovsk Province differed from the Primorsky sample by the amount of costal grooves. Our data confirmed these results (Table 3). Like Misawa (1989), we also failed to discover geographic variation in other species.

\section{Correlating number of trunk vertebrae with count of costal grooves}

Highton (1957) has pointed out the relations between external body segmentation and count of trunk vertebrae in urodelans. Briefly, since early stages of development, the body segmentation (the socalled somites) results both in vertebral column and in muscles (Schmalhausen, 1957, 1958a, 1958b, 1964; Mauger, 1962; Wake \& Lawson, 1973;
Borchwardt, 1974). The segmental borders (or myosepts) lying between the fore- and hindlimbs are externally expressed by costal grooves. Therefore, the number of these grooves should be correlated with the number of trunk vertebrae.

The variation in number of costal grooves is influenced by both the account of trunk vertebrae and the position of limb bases. The former factor was discussed above. The position of bases of limbs varies markedly in various families, genera, species and, sometimes, individuals. Curiously, as far as we could conclude, taxonomically, the position of forelimbs seems to be more conservative in comparison with that of hindlimbs.

Based on our experience with hynobiids, we could propose the following formula to describe the relation between count of costal grooves (CG) and number of vertebrae in the middle part of trunk $\left(\mathrm{TV}_{\text {middle }}\right): \mathrm{CG}=\mathrm{TV}_{\text {middle }}-1$. We suggest that this formula may be applied to other families of urodelans as well, except some rare cases with appearance of additional (secondary) costal grooves.

\section{Taxonomic value}

Various authors suggested several configurations of evolutionary relationships between hynobiids. For instance, based on reproductive biology characters, Thorn (1969) proposed to recognize separate family Ranodontidae, with the genus Ranodon only. Using a set of morphological and biological data, and based on Chinese species, Zhao \& $\mathrm{Hu}$ (1984) also split the family into two "natural" groups: the Hynobius group with predominantly terrestrial species (Hynobius and Salamandrella) and the Ranodon group with predominantly water inhabitants (Ranodon, Onychodactylus, Batrachuperus and Liua). Later, Zhao \& Zhang (1985) separated the genus Pachyhynobius to the third group. Combining of morphological characters and mitochondrial DNA data, Larson \& Dimmick (1993) have found the closest relationships between the genera Salamandrella and Hynobius, thus, confirming traditional acceptance of the similarity of these taxa. However, the genus Onychodactylus was more closely related to the lineage, whereas Batrachuperus (the eastern group) proved to be more distant. Recently, Fei \& Ye (2000a) have erected a new subfamily 
for the newly discovered Protohynobius puxiongensis, whereas all other hynobiids were allocated to another subfamily.

Our present data are not in agreement with all these suggestions, which did not recognize the genus Onychodactylus as a separate lineage. The distinctness of the genus was supported by karyologicall and genome size data (Morescalchi et al., 1979; Olmo, 1983; Kohno et al., 1991; Iizuka, Yazawa, 1994; Vinogradov, 1998; Kuro-o et al., 2000; our unpublished data).

The genus Hynobius may be split into three groups of the subgeneric level (Matsui et al., 1992; Borkin, 1999). However, we failed to find the differences between the representatives of subgenera Hynobius (H. nebulosus, H. leechi, H. nigrescens) and Pseudosalamandra (H. naevis) in terms of numbers of trunk vertebrae and costal grooves.

However, we have found obvious differences in anterior trunk vertebrae number between Batrachuperus pinchonii from the eastern (Chinese) group and $B$. mustersi from the western (Middle East) group. A recent biochemical study revealed that the genus Batrachuperus is not monophyletic, and the eastern species (B. mustersi and B. gorganensis) form a monophyletic group, which is the sister one of the clade comprised of Ranodon, Liua and Pseudohynobius (Fu et al., 2001). Therefore, our comparison fits a separation between the western and the eastern groups of Batrachuperus.

The pattern in geographic variation in number of trunk vertebrae in Salamandrella keyserlingii supports the distinctness of the south-eastern populations of the species evidenced by various other data.

\section{Concluding remarks}

Thus, in hynobiids, the variation in number of trunk vertebrae is within the limits observed in other urodelans. This character could be useful for taxonomy of the family Hynobiidae at the specific and generic levels. We also supported that, at least sometimes, the count of costal grooves could also be important, preferably, for the discrimination of closely related species. The existence of obvious correlation between numbers of trunk vertebrae and of costal grooves allows to evaluate number of the former at the field or museum conditions by means of accounting of external costal grooves (if the number of vertebrae in anterior part of trunk is known) and, thus, to avoid any dissections, x-ray analysis and other damaging and relatively complicated techniques.

\section{Acknowledgements}

We thank to V.G. Borchwardt (St. Petersburg), A.E. Dunaev \& V.F. Orlova (Moscow) who kindly offered the museum collections, T.N. Platonova (St. Petersburg) for correcting the English, and two anonymous reviewers for their valuable comments on the manuscript. The St. Petersburg Association of Scientists and Scholars provided the facilities for preparation of the manuscript. The research was funded by the INTAS (grant no 97-11909), the Russian Foundation for Basic Research (grants no 02-04-49631 and 02-04-63157), and the Federal State Program "Integration" (the grant No. E-0121).

\section{References}

Antipenkova TP. 1982. Tail ribs in amphibians. In: Vorobyeva EI, Iordansky NN, eds. Morphofunctional'nye Preobrazovaniya Pozvonochnykh v Processe Osvoeniya Sushi, Moskow, Nauka, 76-87 (in Russian).

Antipenkova TP. 1994. Axial skeleton. In: Vorobyeva EI, ed. The Siberian Newt (Salamandrella keyserlingii Dybowski, 1870). Zoogeography, Systematics, Morphology, Moskow, Nauka, 153-158 (in Russian).

Arntzen JW, Olgun K. 2000. Taxonomy of the banded newt, Triturus vittatus: morphological and allozyme data. Amphibia-Reptilia 21: 155-168.

Arntzen JW, Wallis GP. 1999. Geographic variation and taxonomy of crested newt (Triturus cristatus superspecies): morphological and mitochondrial DNA data. Contr. Zool. 68(3): 181-203.

Bassarukin AM, Borkin LJ. 1984. Distribution, ecology and morphological variability of the Siberian salamander, Hynobius keyserlingii, of the Sakhalin Island. In: Borkin LJ, ed. Ecology and Faunistics of Amphibians and Reptiles of the USSR and Adjacent Countries. Proc. Zool. Inst. USSR Acad. Sci. Leningrad 124: 12-54 (in Russian).

Borchwardt VG. 1974. Comparative analysis of the vertebral column morphogenesis in Urodela. Zool. Zhurnal, Moscow 53 (11): 1669-1678 (in Russian).

Borkin LJ. 1994. Systematics. In: Vorobyeva EI, ed. The Siberian Newt (Salamandrella keyserlingii Dybowski, 1870). Zoogeography, Systematics, Morphology, Moskow, Nauka, 54-80 (in Russian).

Borkin LJ. 1999. Distribution of amphibians in North Africa, Europe, Western Asia, and the former Soviet Union. In: Duellman WE, ed. Patterns of Distribution of Amphibians: a 
Global Perspective, Baltimore, The Johns Hopkins University Press, 329-420.

Brodie EDJ. 1961. Western salamanders of the genus Plethodon: systematics and geographic variation. Herpetologica 26: 468516.

Brushko ZK, Kubykin 'RA, Narbaeva SP. 1988. Recent distribution of Siberian salamander Ranodon sibiricus (Amphibia, Hynobiidae) in Dzungar Alatau. Zool. Zhurnal, Moscow 67: 1753-1756 (in Russian).

Chan LN, Zamudio KR, Wake DB. 2001. Relationships of the salamandrids genera Paramesotriton, Pachytriton, and Cynops based on mitochondrial DNA sequences. Copeia 2001(4): 997-1009.

Chang MLY. 1936. Contribution à l'otude morphologique, biologique et systématique des Amphibiens urodèles de la Chine. Paris: Librairie Picart.

Cope ED. 1889. The Batrachia of North America. Washington: Government Printing Office.

Crnobrnja-Isailović J, Džukić G, Kristić N, Kalezić ML. 1997. Evolutionary and paleogeographical effects on the distribution of the Triturus cristatus superspecies in the central Europe. Amphibia-Reptilia 18: 321-332.

Deynegi VA. 1917. To the knowledge on structure and development of Ranodon sibiricus Kessl. Bull. Soc. Imper. Nat. Moscou, An. 1916, N.S. 30: 291-320 (in Russian).

Duellman WE, Trueb L. 1986. Biology of Amphibians. New York: McGraw-Hill Book Co.

Dunn ER. 1923. The salamanders of the family Hynobiidae. Proc. Amer. Acad. Arts Sciences, Northampton 58(13): 445523.

Estes R. 1981. Gymnophiona, Caudata. Encyclopedia of Paleoherpetology, 2. Stutgart-New York: Gustav Fisher.

Fei L, Ye C. 2000a. A new hynobiid subfamily with a new genus and new species of Hynobiidae (Amphibia: Caudata) from West China. Cultum Herpetol. Sinica 8: 64-70.

Fei L, Ye C. 2000b. The colour handbook of the amphibians of Sichuan. (in Chinese)

Frolich LM. 1991. Osteological conservatism and developmental constraint in the polymorphic "ring species" Ensatina eschscholtzii (Amphibia: Plethodontidae). Biol. J. Linn. Soc. 43: 81-100.

Fu J, Wang Y, Zeng X, Liu Z, Zheng Y. 2001. Genetic diversity of eastern Batrachuperus (Caudata; Hynobiidae). Copeia 2001: 1100-1105.

Gerecht A. 1929. Über die Richtung der phyletischen Wanderung der Sakralregion bei Triton cristatus und Triton taeniatus. Bul. Soc. Biol. Lettonie 1(1): 9-19.

Good DA, Wake DB. 1992. Geographic variation and speciation in the torrent salamanders 'of the genus Rhyacotriton (Caudata: Rhyacotritonidae). Univ. Calif. Publ. Zool. 126: 1-91.

Highton R. 1957. Correlating costal grooves with trunk vertebrae in salamanders. Copeia 1957(2): 107-109.

Highton R. 1960. Heritability of geographic variation in trunk segmentation in red-backed salamander, Plethodon cinereus. Evolution 14: 351-360.

Highton R. 1962. Revision of North American salamanders of the genus Plethodon. Bull. Fla. Stat. Mus., 6: 235-367.
Highton R, Grobman AB. 1956. Two new salamanders of the genus Plethodon from the southeastern United States. Herpetologica 12: 185-188.

Hilton WA. 1948. The vertebrae of salamanders. J. Entom. Zool. 40(3): 47-65.

Hoffmann CK. 1878 [1873-1878]. Dr. H. G. Bronn's Klassen und Ordnungen der Amphibien wissenschaftlich dargestellt in Wort und Bild. Leipzig-Heidelberg: C.F. Winter'sche Verlagshandlung.

Iizuka K, Yazawa S. 1994. The karyotype, C-bands and $\mathrm{AgNO}_{3}$ bands of a lungless salamander from Korea: Onychodactylus fischeri (Boulenger) (Amphibia, Urodela). Experientia 50: 171-175.

Jockusch EL. 1997. Geographic variation and phenotypic plasticity of number of trunk vertebrae in slender salamanders, Batrachoseps (Caudata: Plethodontidae). Evolution, 51(6): 1966-1982.

Kohno S, Kuro-o M, Ikebe C. 1991. Cytogenetics and evolution of hynobiid salamanders. In: Green DM, Sessions SK, eds. Amphibian Cytogenetics and Evolution, San Diego, Academic Press Inc., 67-88.

Korotkov YM. 1977. A contribution to the ecology of Onychodactylus fisheri and Hynobius keyserlingii in Primorsky District. Zool. Zhurnal, Moscow 56: 1258-1260 (in Russian).

Kuro-o M, Haségawa Y, Ikebe C, Wu G, Zeng X, Kohno S, Obara Y. 2000. Turtle biodiversity: global data for the global community [correct title: Molecular cytogenetic approach to deduction of phylogenetic relationships in hynobiid salamanders]. In: Fourth Asian Herpetol. Conf., Chendu, 97-98.

Kuzmin SL. 1990. Feeding of sympatric species of the Hynobiidae in the Primorye. Zool. Zhurnal, Moscow 69: 7175 (in Russian).

Kuzmin SL, Kubykin RA, Thiesmeier B, Greven H. 1998. The distribution of the Semirechensk salamander (Ranodon sibiricus): a historical perspective. Advances in Amphibian Research in the Former Soviet Union, Moscow 3: 1-20.

Kuzmin SL, Thismeier B. 2001. Mountain salamanders of the genus Ranodon. Advances in Amphibian Research in the Former Soviet Union, Moscow 6: 1-184.

Lanza B, Gentile E, Torricelli I. 1994. Preliminary data on the number of presacral vertebrae in Triturus cristatus - Artenkreis (Amphibia: Caudata: Salamandridae). In: Ghiara G. et al., eds. Symposium on the Evolution of Terrestrial Vertebrates. Selected Symposia and Monographs U.Z.I., 4, Modena, Mucchi, 531-534.

Larson A, Dimmick WW. 1993. Phylogenetic relationships of the salamander families: an analysis of congruence among morphological and molecular characters. Herpetol. Monographs 7: 77-93.

Lindsey CC. 1966. Temperature-controlled meristic variation in the salamander Ambistoma gracile. Nature 209(5028): 1152-1153.

Litvinchuk SN. 1998. Systematics and distribution of the newts of Triturus cristatus complex (Salamandridae) in Russia and adjacent countries. Unpublished Ph.D. thesis., St. Petersburg: Zoological Institute Russian Academy of Sciences (in Russian). 
Litvinchuk SN, Borkin LJ. 2000. Intraspecific taxonomy and nomenclature of the Danube crested newt, Triturus dobrogicus. Amphibia-Reptilia 21: 419-430.

Litvinchuk SN, Rosanov JM, Borkin LJ. 2001a. Natural autotriploidy in the Danube newt, Triturus dobrogicus (Salamandridae). Russ. J. Herpetol. 8(1): 74-76.

Litvinchuk SN, Rosanov JM, Borkin LJ, Khalturin MD, Timofeev BI, Džukić G, Kalezić ML. 2001 b. Genome size and some problems of urodelan systematics (Salamandridae and Hynobiidae). In: Ananjeva NB et al., eds. The Problems of Herpetology, Pushchino-Moscow, Moscow State Univ., 168-170. (in Russian)

Lucas FA. 1886. The sacrum of Menopoma. Amer. Nat. 20(5): 561-562.

Lynch JF. 1981. Patterns of ontogenetic and geographic variation in the black salamander, Aneides flavipunctatus (Caudata: Plethodontidae). Smithsonian Contr. Zool. 324: 1-53.

Matsui M, Sato T, Tanabe S, Hayashi T. 1992. Electrophoretic analyses of systematic relationships and status of two hynobiid salamanders from Hokkaido (Amphibia: Caudata). Herpetologica 48: 408-416.

Mauger A. 1962. Organogénèse de la colonne vertébrale et des côtes chez l'Urodèle Pleurodeles waltl Michahelles. Bull. Soc. Zool. France 87(1): 163-187.

Meyer-Rochow VB, Asashima M. 1988. Naturally occurring morphological abnormalities in wild populations of the Japanese newt Cynops pyrrhogaster (Salamandridae; Urodela; Amphibia). Zool. Anz. 221(1/2): 70-80.

Misava Y. 1989. The method of counting costal grooves. In: Matsui M et al., eds. Current Herpetology in East Asia, Kioto, Herpet. Soc. Japan, 129-134.

Mivart G. 1870. On the axial skeleton of the Urodela. Proc. Zool. Soc. London: 260-278.

Moment GB. 1949. The number of caudal vertebrae in a caudate amphibian, Triturus viridescens, in relation to growth. Anat. Rec. 1949: 711-719.

Morescalchi A, Odierna G, Olmo E. 1979. Karyology of the primitive salamanders, family Hynobiidae. Experientia 35: 1434-1436

Nambu H. 1991. Hynobius tenuis (Caudata, Hynobiidae), a new species of salamander from central Japan. Zool. Sci. 8: 991997.

Nussbaum RA. 1976. Geographic variation and systematics of salamanders of the genus Dicamptodon Strauch (Ambystomatidae). Misc. Publ. Mus. Zool. Univ. Michigan 149: 1-94.

Okajima K. 1908. Die Osteology des Onychodactylus japonicus. Z. wissensch. Zool. 91(3): 351-381.

Olmo E. 1983. Nucleotype and cell size in vertebrates: a review. Bas. Appl. Histochem. 27: 227-256

Orska J, Imiolek Z. 1962. Wstepne badania nad wplywem temperatury na rozwoj cech merystycznych u plazow ogoniastych (Urodela). Acta Univ. Wratislaviensis, WarszawaWroclaw 3(Prace zool., 1): 135-154.

Ostashko NG. 1981. Geographical variation in the Siberian salamander (Hynobius keyserlingii). In: Darevsky IS, ed. The Problems of Herpetology, Leningrad, Nauka, 98 (in Russian).

Parker GH. 1896. Variations in the vertebral column of Necturus. Anat. Anzeiger 11: 711-717.
Parra-Olea G, Wake DB. 2001. Extreme morphological and ecological homoplasy in tropical salamanders. Proc. Nat. Acad. Sci. 98(14): 7888-7891.

Peabody RB, Brodie ED. 1975. Effect of temperature, salinity and photoperiod on the number of trunk vertebrae in Ambystoma maculatum. Copeia 1975(4): 741-746.

Rabb GB. 1965. A new salamander of the genus Chiropterotriton (Caudata: Plethodontidae) from Mexico. Breviora, Mus. Compar. Zool. 235: 1-8.

Sapozhnikov GP. 1990. Some peculiarities of larval development and growth of Salamandrella keyserlingii. In: Salmanov AV, Darevsky IS, eds. Investigations on Zoology of Vertebrates. Proc. Zool. Inst. USSR Acad. Sci. Leningrad 213: 7590 (in Russian).

Schmalhausen II. 1957. Morphology of urodelan vertebral column, I. Zool. Zhurnal, Moscow, 36(11): 1717-1734 (in Russian).

Schmalhausen II. 1958a. Morphology of urodelan vertebral column, II. Zool. Zhurnal, Moscow, 37(2): 229-239 (in Russian).

Schmalhausen II. 1958b. Morphology of urodelan vertebral column, III. Zool. Zhurnal, Moscow, 37(3): 415-429 (in Russian).

Schmalhausen II. 1964. The origin of terrestrial vertebrates. Moscow: Nauka (in Russian).

Sket B, Arntzen JW. 1994. A black, non-troglomorphic amphibian from the karst of Slovenia: Proteus anguinus parkelj n. ssp. (Urodela: Proteidae). Bijdrag. Dierkunde, 64(1): 3353.

Smallwood WM. 1908. The sacrum of Necturus. Anat. Anz. 33(8/ 9): 237-239.

Song M, Zeng X, Wu G, Liu Z, Fu J. 2001. A new species of Batrachuperus from Northwestern China. Asiatic Herpet. Research 9: 6-8.

Stöck M. 1999. On the biology and the taxonomic status of Batrachuperus gorganensis Clergue-Gazeau et Thorn, 1979 based on topotypic specimens (Amphibia: Caudata: Hynobiidae). Zool. Abh. Staatl. Mus. Tierk. Dresden, 50: 217241.

Teege M-J. 1957. Studien zur Entwicklung und Gestalt der Urodelenwirbel. Z. wissensch. Zool. (Abt. A), 160: 95-163.

Thorn R. 1969 [1968]. Les Salamandres d'Europe, d'Asie et d'Afrique du Nord. Paris: Paul Lechevalier.

Thorn R., Raffaëlli J. 2001. Les Salamandres de l'Ancien Monde. Paris: Boubée.

Vinogradov AE. 1998. Genome size and GC-percent in vertebrates as determined by flow cytometry: the triangular relationship. Cytometry 31: 100-109

Vorobyeva EI. 1994. Introduction. In: Vorobyeva EI, ed. The Siberian Newt (Salamandrella keyserlingii Dybowski, 1870). Zoogeography, Systematics, Morphology. Moskow, Nauka, 5-7 (in Russian).

Vorobyeva EI, Antipenkova TP, Hinchliff JR. 1999. The peculiarities of limbs development from Far East population of the Siberian newt (Salamandrella keyserlingii, Hynobiidae, Caudata). Doklady Rossiyskoy Akademii Nauk 364: 130-133 (in Russian).

Waite FC. 1897. Variations in the brachial and lumbo-sacral 
plexi of Necturus maculosus Rafinesquie. Bull. Mus. Comp. Zool. 31(4): 71-92.

Wake DB, Lawson R. 1973. Developmental and adult morphology of the vertebral column in the plethodontid salamander Eurycea bislineata, with comments on vertebral evolution in the Amphibia. J. Morph., 139(3): 251-300.

Worthington RD, Wake DB. 1972. Patterns of regional variation in the vertebral column of terrestrial salamanders. $J$. Morph., 137(3): 257-278.

Zhang F. 1985. On anatomy of the skeletal system of Liua shihi (Liu) (Amphibia, Hynobiidae). Acta Herpet. Sinica 4(1): 1724. (in Chinese)

Zhao E, Hu Q. 1984. Studies of Chinese Tailed Amphibians. Chengdu: Sichuan Sci. \& Tech. Publ. House. (in Chinese; 1988, Soc. Study Amphibians and Reptiles, Oxford, English version)

Zhao E, Zhang F. 1985. The aquatic evolution of Hynobiidae of China, with descriptions of a new genus and a new species from Western Anhui. Acta Herpet. Sinica 4(3): 36-40. (in Chinese)

Accepted: 29 October 2002

\section{Appendix}

Batrachuperus mustersi - Paghman River, Afghanistan.

Batrachuperus pinchonii - Zhaojiao Village, Sichuan, China.

Hynobius leechii - Yugems Village, Korea; Chanchun' Town, China.

Hynobius naevis - Nagasaki Town and unknown locality, Japan.

Hynobius nebulosus - Unknown locality, Japan.

Hynobius nigrescens - Okushiobara Town, Tochigi Prefecture, Japan.

Onychodactylus fischeri - Ussuriysk Reserve, Primorsky Territory, Russia.

Onychodactylus japonicus - Kusatsu Village, Gumma Prefecture, Japan.

Ranodon sibiricus - Kopal Town, Chambulak River in the vicinity of Tekeli Town, Balykty River and Jukentas Pass, TaldyKurgan Province, Kazakhstan.

Salamandrella keyserlingii - 1. Chur Village, Udmurt Republic, Russia; 2. Ekaterinburg City, Russia; 3 . Tomsk City, Russia; 4. Kyakhta Town, Buryatia Republic, Russia; 5. Ulan Bator City, Dzun Buren and Shamar villages, Mongolia; 6. Yakutsk Town, Russia; 7. Ust Srednekan Town, Magadan Province, Ruśsia; 8. Kamaki Village, Kamchatka Province, Russia; 9. Chernyaevo Village, Amur Province, Russia; 10. Vyazemsky and Lesopilnoe villages, Khabarovsk Territory, Russia; 11. Shmakovka, Chernikovka and Troitskoe villages, Dalnerechensk, Kamen-Rybolov and Vladivostok towns, Ussuriysk and Kedrovaya Pad reserves, Primorsky Territory, Russia; 12. Dachuan Village, China. 